\title{
It Depends on the Size: How Firm Strategic Emphasis on Digital Transformation Predicts Market Capitalization
}

\author{
Anna Moker \\ Technical University of Munich \\ anna.moker@tum.de
}

\author{
Prisca Brosi \\ Kühne Logistics University \\ prisca.brosi@the-klu.org
}

\author{
Isabell M. Welpe \\ Technical University of Munich \\ welpe@tum.de
}

\begin{abstract}
Whereas digital businesses can have an enormous market value, it remains an open question, whether firms, embarking on a digital transformation journey, can realize similar benefits. Thus, we rely on the signaling theory to study, whether strategic emphasis on digital transformation - i.e., the extent, to which a firm focuses on digital transformation in its strategy as well as firm size as an indicator of a large resource basis jointly influence market capitalization. To answer this question, we conducted a longitudinal panel data analysis of the largest German publicly listed companies from 2000 to 2017. Our results show, that strategic emphasis on digital transformation leads to a higher market capitalization for larger firms and to a lower market capitalization for smaller firms. Whereas larger firms should further disclose their strategic emphasis on digital transformation, smaller firms should consider sending additional signals to investors, demonstrating their ability to undergo digital transformation successfully.
\end{abstract}

\section{Introduction}

Digital businesses can realize an enormous market value [1]. For instance, five out of ten companies with the largest market value worldwide in 2019 are born digital pioneers [2, 3]: Amazon, Alphabet, Facebook, Alibaba, and Tencent [4]. Unsurprisingly, many predigital organizations, i.e., established firms from traditional industries, seek to realize similar benefits by starting to transform digitally $[2,3,5]$. Applying digital technologies such as mobile, social media, analytics, cloud, Internet of things, and platforms [2, 3, 6, 7], they comprehensively transform their business, structure, processes and products to enable major business improvements such as enhanced customer experience, streamlined operations and new value propositions $[3,6,7]$.
Yet, it remains an open question, whether firms, embarking on a digital transformation journey, can indeed realize a higher market value. Despite the growing interest of information systems researchers in the digital transformation [7], existing research on the success and risks of digital transformation is scarce and fragmented [2, 3]. This research is limited to case studies, describing signals of improved use of digital technologies as well as possible digital transformation strategies for established firms [2, 5, 8-12]. Hence, empirical evidence on the link between firms' signals of digital transformation and stock market reactions to them is missing [3]. This gap is of substantial importance, as the stock market is likely to react to such signals [13, 14], and firms, facing many challenges on their digital transformation paths, need to anticipate them $[2,3,5]$.

To address this research gap, we consider firm strategic emphasis on digital transformation, which we define as the extent, to which a firm focuses on digital transformation topics in its corporate strategy $[15,16]$, and its link to firm valuation on a stock market. Our first research question is: How does firm strategic emphasis on digital transformation influence its market capitalization? To investigate this relationship, we rely on signaling theory [17-19]. According to signaling theory, in order to reduce existing information asymmetry, observers such as investors seek out visible signals of a company to be able to assess its unobservable attributes such as strategic decisions and their likely performance outcomes [17-19]. Thus, if a firm discloses its strategic emphasis on digital transformation, investors might use this information to adjust their interest in firm's shares, leading to changes in market capitalization.

Yet, firms' signals about their digital transformation might be ambivalent for investors because digital transformation requires a plenty of resources such as human, information, and financial resources [2, 5, 20-22]. One typical and highly visible indicator of a large resources base is large firm size [23]. Thus, depending on firm size, investors might react to signals of firm strategic emphasis on digital 
transformation with an increasing or decreasing interest in firm shares. Accordingly, we also study, how the relationship between firm strategic emphasis on digital transformation and market capitalization might vary depending on firm size. Our second research question is: Does firm size moderate the relationship between firm strategic emphasis on digital transformation and its market capitalization? To investigate these research questions, we conducted a longitudinal panel data analysis of the largest German publicly listed firms (HDAX) between 2000 and 2017.

With this study, we extend research on digital transformation of companies $[2,3,5,7,11,24]$ in two ways. First, by exploring the effect of strategic emphasis on digital transformation on firm evaluation on a stock market, we respond to a call of existing studies to investigate the questions related to success, risks and failures of digital transformation for firms [3]. In doing so, we are to our best knowledge the first to provide quantitative empirical evidence on strategic emphasis on digital transformation in firms and its influence on their performance in a longitudinal study over 17 years using panel data [7]. Second, due to examining the effects of an interplay between firm strategic emphasis on digital transformation and firm size on market capitalization, we draw attention to firm characteristics, which might promote or hamper the realization of the benefits, connected with the digital transformation process. Thus, we extend the digital transformation framework as proposed by Vial [7] by adding outcomes to the buildings blocks of positive and negative impacts of digital transformation and proposing an additional building block of contextual factors, which might influence the path between the changes in value creation paths and digital transformation impacts.

Our study is also important for practitioners, who are embarking on a digital transformation journey [3, 5]. First, we draw their attention to the fact, that strategic emphasis on digital transformation, as signaled by their firms, can matter for firm market capitalization. Second, we provide evidence on which stock market reactions to strategic emphasis on digital transformation firms might anticipate, depending on their size. By highlighting these possible outcomes of the digital transformation process [7], we aim at supporting firms on their digital transformation path.

\section{Theoretical background and hypotheses}

The goal of digital transformation is to improve a firm, which is undergoing it [7]. Hence, research on digital transformation of companies has highlighted different performance benefits, which a firm can realize during the process of digital transformation [6, 7]. These benefits include improved operational efficiency, such as cost savings, business process improvement, and automation, as well as better organizational performance, such as firm growth, higher innovativeness, improved financial performance and competitive advantage [7]. Digital transformation further enables firms to explore new paths of value generation and create new business models [3, 5, 7, 21]. Thereby, digital transformation not only leads a higher firm competitiveness, but also provides a basis for its persistence on the market, contributing to a better long-term firm performance [5, 7].

Yet, not all firms might be able to realize these benefits, as digital transformation presents a very complex endeavor, which is hallmarked by a high degree of uncertainty and entails a risk of failure $[2,3$, $5,6,25]$. One of the most common reasons for failure of digital transformation's initiatives is the lack of resources, required for digital transformation, such as information, human and financial resources $[2,5,6$, 20-22]. For instance, firms need knowledge and expertise to define a digital transformation strategy, employ new digital technologies as well as develop digital services platforms and operational backbones $[2,5,21,24]$. Further, firms require experienced executives such as Chief Digital Officers (CDO) to identify the right digital business opportunities and navigate digital transformation [20, 24], as well as qualified employees, who can take over new roles and responsibilities in firm's IT function and other departments $[2,7]$. Finally, to finance these employees, to develop digital services platforms and finance other aspects of digital transformation, firms require financial resources $[5,6,21]$. Thus, firms, which seek to navigate digital transformation successfully, need a large resource basis [5, 21].

A primary indicator of such a broad resource base is firm size [23, 26-28]. Prior research has shown that larger firms possess larger pools of managerial and financial resources $[26,28]$, which can be invested into digital transformation projects [23]. These resources pools can also be used to bear the risks and costs of digital transformation [23, 26, 28]. Further, larger firm size increases a firm's potential to attract additional resources such as external knowledge networks [23], well-trained employees, further capital, favorable tax conditions and governmental regulations [26, 27]. Additionally, larger firms are usually powerful market players, which do not only have a better access to needed resources, but can also prevent other market participants of gaining access to such resources [23, 29]. Accordingly, larger firms face a decreased risk of failure in digital transformation initiatives [26-28, 30]. Further, even if it comes to a failure, the associated 
losses would not threaten the survival of larger firms [26-28, 30]. Hence, performance expectations for larger firms, undergoing digital transformation, are likely to be positive [23]. In contrast, this might not apply to smaller firms, which possess a smaller stock of resources, and are thus much more vulnerable to firm failure and financial losses, which might threaten their survival [26-28, 30].

According to signaling theory [17-19], as digital transformation is bound to risk and uncertainty $[2,3,5$, 6, 25], stakeholders such as investors seek out to reduce the arising information asymmetry. Hence, they look out for observable actions and visible signals of a company to be able to assess its strategic position concerning digital transformation and its likely performance outcomes [17-19]. Hereby, investors can rely on such visible signals as firm strategic emphasis on digital transformation, as reflected in firm's annual reports as a central mean of corporate strategy's communication to external stakeholders [31], as well as firm size as an indicator of a sufficient resources base for digital transformation [5, 21, 23, 26-28, 30]. Thus, if a larger firm discloses a higher strategic emphasis on digital transformation, investors will be likely to assess this firm as having a higher probability of successfully managing its digital transformation and realizing the corresponding performance benefits [6, 7]. Hence, investors, who consider buying company's stock, will be willing to pay a higher price for it, resulting in an increased stock price and market capitalization $[13,14,32]$. As opposed to this, a smaller firm's disclosure of a higher strategic emphasis on digital transformation can signal an endeavor with a higher risk of failure to investors, resulting in lower performance expectations for this firm [26-28]. Thus, potential investors' interest in a firm stock will decrease, leading to a lower market capitalization [13, 14, 32]. Accordingly, we hypothesize:

Hypothesis. A higher strategic emphasis on digital transformation is associated with a higher market capitalization for larger firms, and a lower market capitalization for smaller firms.

\section{Methods}

\subsection{Sample and procedure}

To test our hypotheses, we conducted a panel data analysis from 2000 to 2017 using a sample of the German firms, listed on the public stock index HDAX. It covers 110 largest German stock corporations, including the 30 largest German companies (DAX), the next 50 largest companies (MDAX) as well as the 30 largest technology companies (TecDAX). As TecDAX emerged in 2003, until then HDAX incorporated 30 DAX and 70 MDAX companies [33]. Besides including publicly listed firms, this sample is suitable for our study for three further reasons. First, HDAX includes firms of different industries. Therefore, we expect the firms in our sample to exhibit different degrees of strategic emphasis on digital transformation [3]. Second, HDAX encompasses not only large companies, but also mid-sized and smaller technology firms. Hence, it generates both variance in market capitalization and firm size among the considered companies [34]. Third, this sample has frequently been used by prior studies [e.g., 34, 35], verifying its suitability to study organizational phenomena.

To construct our sample, we included those companies, which were a member of HDAX as of December, 30th for each year from 2000 to 2017. The year 2012 was the only exception, as we had to use the data as of December, 28th 2012 due to a missing availability of later data for this year. Because we accounted for changes in the HDAX composition, our data was unbalanced.

We gathered our data from three main sources. First, we obtained the list of companies, which were a member of HDAX in each year, from STOXX Ltd., a part of Deutsche Börse Group. Second, we collected firm data from the database Wordscope (Thomson One Banker), which has already been utilized as a source of firm data by existing studies [e.g., 35]. Third, we gathered data on firm strategic emphasis on digital transformation from the annual reports.

We faced the problem of missing data [34, 36, 37], especially with respect to firm financial data and Research \& Development (R\&D) expenditures. Our sample was further reduced because we used lagged values (t-1) for all our independent variables [38-40], as prior research has shown, that capital markets usually need some time to incorporate the available firm information [41, 42]. Hence, our final sample comprised 1,203 firm-year observations.

\subsection{Measures}

We measured our dependent variable, market capitalization, as firm's market capitalization in the respective year in Euro.

We measured our independent variable, firm strategic emphasis on digital transformation, as the count of words, related to digital transformation, by 1,000 words in a firm's annual report [43]. For this purpose, we counted the absolute number of words, beginning with "digit*", divided it by the total number of words in an annual report in the respective year [31], and then multiplied the result with a factor of 1,000 [43]. This measurement approach is appropriate for our 
study for three main reasons. First, both in German and English languages, the root word "digit*" covers a wide range of words, connected with digital transformation, such as "digital" (transformation, markets, products, processes, technologies, strategies, etc.), "digitalization", “digitization", etc. Second, annual reports constitute a representative form of firm's communication, which does not noticeably differ in its language choice from other sources of organizational communication such as press releases [31]. Annual reports are directed at external stakeholders such as investors or financial analysts, who use these reports as a central information source in order to understand firm's strategic decisions [31]. Indeed, not only financial analysts [44], but also investors can be expected to read companies' qualitative announcements in the form of annual reports [44-46]. Hereby, especially long-term oriented investors, who are interested in a future development of firm's strategic and intangible assets such as strategic emphasis on digital transformation, usually have profound skills in monitoring and detecting the relevant information, which is positioned outside the balance sheet in firm's annual reports [47]. Third, a word-count approach in annual reports or their selected parts has been widely used in strategic management research to approach an orientation of a company or its executives [e.g., 31, 43, 48]. Therefore, the chosen operationalization of firm strategic emphasis on digital transformation is capable of covering company's language, related to digital transformation; relies on a data source, which addresses appropriate stakeholders; presents a suitable means of expressing strategic emphasis of a firm; and is a representative and valid source of a firm's strategy communication [31]. To implement this operationalization, we developed a supporting macro in Microsoft Excel 2016, which counted the words, beginning with "digit*" as well as the total number of words, in firms' annual reports in each year.

Additionally, this macro also recoded the words, beginning with "digit*" as well as the words, which followed them. Table 1 shows the ten most frequently used words of the both groups. The most frequently used word, beginning with "digit*", was "digital" in its different declensions $(\mathrm{n}=77.47 \%)$, followed by "digitalization" $(\mathrm{n}=14.19 \%)$ and "digitalized" $(\mathrm{n}=$ $0.98 \%$ ). The ten presented most frequently used words accounted for $95.35 \%$ of all words, beginning with "digit*". Considering words, which followed those containing "digit*", the most frequently found word was "lifestyle" ( $n=2.69 \%)$, followed by "adjacent" (n $=2.51 \%)$ and "media" $(\mathrm{n}=2.47 \%)$. The ten presented most common second words accounted for $16.37 \%$ of all words, which followed those containing "digit*".
Overall, these words indicate strategically relevant topics, connected with digital transformation of companies, thus providing support for our measure.

We measured firm size as the natural logarithm of the number of firm's employees [49], which represents a reliable measure of an overall firm size in a given industry [26].

Additionally, we controlled for firm's $R \& D$ expenditures in order to address the magnitude of the required financial resources for the ongoing digital transformation projects [50, 51], firm performance as well as industry performance as these factors could both influence firm strategic emphasis on digital transformation and market capitalization $[42,52]$. We measured R\&D expenditures as the total amount of firm's R\&D expenses in Euro divided by the number of employees [52]. We operationalized firm performance as Return on Assets (ROA) [31]. We measured industry performance as the average ROA values of all firms operating in the firm's industry [42] according to the Industrial Classification Benchmark [53]. Further, we controlled for the presence of a $C D O$. The presence of this executive might influence strategic emphasis on digital transformation by leveraging digital transformation [20, 24, 54] such as helping the Chief Executive Officer (CEO) to infuse the digital transformation strategy into all business areas [11]. Further, the presence of a CDO can influence market capitalization by making the formulation of the digital transformation strategy more focused and sending an additional signal to the investors [11]. We collected information on the presence of the CDO position from firms' web pages and their annual reports, and performed an internetbased search via the search engine Google to verify the results. CDO was coded 1 if a position with the title "Chief Digital Officer" or "CDO" existed in the company or there was a board member, who was responsible for digital transformation topics (identified as any words including the letter combination "digit*" in the area of the responsibility), and 0 otherwise. Finally, to account for macroeconomic trends or shocks such as the financial crisis of 2007-2008, which could have influenced both firm strategic emphasis on digital transformation and market capitalization, we also included year fixed effects into our model [55].

\subsection{Analysis}

To estimate the effect of firm strategic emphasis on digital transformation and firm size on market capitalization, we used a panel data analysis in Stata 14.1. We calculated a fixed effects model, which uses a 
Table 1. Ten most frequently used words, beginning with "digit", and following them

\begin{tabular}{|c|c|c|c|c|c|}
\hline \multicolumn{3}{|c|}{ "Digit*" words } & \multicolumn{3}{|c|}{ Following words } \\
\hline Word & Frequency & Percent & Word & Frequency & Percent \\
\hline Digital $^{a}$ & 13,483 & $77.47 \%$ & Lifestyle $^{c}$ & 458 & $2.69 \%$ \\
\hline Digitalization & 2,470 & $14.19 \%$ & Adjacent ${ }^{c}$ & 427 & $2.51 \%$ \\
\hline Digitalized ${ }^{a}$ & 170 & $0.98 \%$ & Media & 420 & $2.47 \%$ \\
\hline Digital printing b & 108 & $0.62 \%$ & Transformation & 284 & $1.67 \%$ \\
\hline Digital cameras ${ }^{b}$ & 83 & $0.48 \%$ & World & 246 & $1.45 \%$ \\
\hline Digitalization strategy ${ }^{b}$ & 69 & $0.40 \%$ & Business $^{c}$ & 211 & $1.24 \%$ \\
\hline Digitalize & 67 & $0.38 \%$ & Company & 208 & $1.22 \%$ \\
\hline Digital business ${ }^{b}$ & 62 & $0.36 \%$ & Entertainment ${ }^{\mathrm{c}}$ & 197 & $1.16 \%$ \\
\hline Digital sector b & 50 & $0.29 \%$ & Subscriber ${ }^{\mathrm{c}}$ & 179 & $1.05 \%$ \\
\hline Digital technology b & 33 & $0.19 \%$ & Limited liability company $(\mathrm{GmbH})$ & 156 & $0.92 \%$ \\
\hline Total & & $95.35 \%$ & & & $16.37 \%$ \\
\hline
\end{tabular}

Note: Analysis for 2000-2016 due to lagged values. Translation from German. ${ }^{\text {a }}$ includes different declensions of this word in German. ${ }^{b}$ is written as one word in German. ${ }^{c}$ not translated.

within-firm variation in independent and dependent variables and allows for arbitrary correlation between the unobserved effect and the independent variables $[56,57]$. By these means, a fixed effects model allows to control for any unobserved firm-specific heterogeneity, which could play a role for performance outcomes [57, 58]. This makes a fixed effects model more convincing for estimating ceteris paribus effects, especially when the used sample cannot be treated as a random sample from a large population of firms [57]. To additionally control for any kind of serial correlation and heteroscedasticity, we allowed for unobserved firm effects in our data by using robust standard errors [57]. Hence, we used the command xtreg, fe cluster(id) in Stata. Due to using a fixed effects estimator in combination with robust standard errors, it was not possible to calculate a Hausman test for the comparison between fixed and random effects [57]. Further, we calculated simple slopes of the interaction between strategic emphasis on digital transformation and firm size on market capitalization using the margins, $d y d x$ command in Stata.

\section{Results}

Table 2 reports descriptive statistics and correlations for our variables. Although some correlations between independent variables were significant, none of them exceeded the critical value, which is considered 0.80 or higher $[59,60]$. Hence, multicollinearity did not appear to present a problem for our data. Table 3 presents the results of a fixedeffects regression for our Hypothesis. Figure 1 shows an interaction graph for strategic emphasis on digital transformation and firm size on market capitalization.

\subsection{Hypothesis testing}

Our Hypothesis predicted that a higher strategic emphasis on digital transformation would be associated with a higher market capitalization for larger firms, and a lower market capitalization for smaller firms. When the interaction effect between strategic

Table 2. Descriptive statistics and correlations

\begin{tabular}{|c|c|c|c|c|c|c|c|c|c|}
\hline Variable & Obs. & Mean & SD & 1 & 2 & 3 & 4 & 5 & 6 \\
\hline $\begin{array}{l}\text { 1. Market capitalization (100 } \\
\text { million) }\end{array}$ & 1,946 & 95.280 & 167.472 & & & & & & \\
\hline $\begin{array}{l}\text { 2. Strategic emphasis on } \\
\text { digital transformation } \mathrm{t}-1\end{array}$ & 1,679 & 0.141 & 0.401 & 0.005 & & & & & \\
\hline 3. Firm size $\mathrm{t}_{\mathrm{t}-1}$ & 1,674 & 9.371 & 1.946 & $0.569^{*}$ & $-0.064^{*}$ & & & & \\
\hline 4. $\mathrm{CDO}_{\mathrm{t}-1}$ & 1,682 & 0.024 & 0.152 & $0.252^{*}$ & $0.287^{*}$ & $0.096^{*}$ & & & \\
\hline $\begin{array}{l}\text { R\&D expenditures } \\
\text { (thousand) } \mathrm{t}_{-1}\end{array}$ & 1,213 & 12.603 & 21.347 & 0.033 & 0.047 & $-0.305^{*}$ & 0.044 & & \\
\hline Firm performance ${ }_{t-1}$ & 1,661 & 5.375 & 7.566 & -0.025 & 0.027 & $-0.093^{*}$ & -0.008 & $-0.127^{*}$ & \\
\hline Industry performance $\mathrm{t}_{\mathrm{t}-1}$ & 1,661 & 5.080 & 1.871 & $0.080^{*}$ & $0.080^{*}$ & $0.193^{*}$ & -0.004 & 0.013 & $0.205^{*}$ \\
\hline
\end{tabular}

Note: ${ }^{*} p<.05$. 
Table 3. Results of a fixed effects regression with robust standard errors

\begin{tabular}{|c|c|c|c|}
\hline & Model1 & Model 2 & Model3 \\
\hline Intercept: & 0.587 & 0.568 & 0.462 \\
\hline \multicolumn{4}{|l|}{ Controls: } \\
\hline$R \& D$ expenditures $t-1$ & 0.052 & 0.063 & 0.073 \\
\hline Firm performance $\mathrm{t}-1$ & -0.042 & -0.036 & -0.016 \\
\hline Industry performance $\mathrm{t}-1$ & -3.226 & -3.225 & -2.857 \\
\hline $\mathrm{CDO}_{\mathrm{t}-1}$ & 0.770 * & $0.775^{*}$ & $0.643^{+}$ \\
\hline \multicolumn{4}{|l|}{ Main effects: } \\
\hline Strategic emphasis on digital transformation $\mathrm{t}-1$ & & 0.067 & 0.059 \\
\hline Firm size $\mathrm{t}-1$ & & 0.264 & $0.328^{+}$ \\
\hline \multicolumn{4}{|l|}{ Interaction effect: } \\
\hline Strategic emphasis on digital transformation $\mathrm{t}-1$ x Firm size $\mathrm{t}-1$ & & & 0.252 ** \\
\hline F-statistic & $5.06^{\star \star \star}$ & $5.21^{\star * *}$ & $5.80^{* * *}$ \\
\hline R-sq within & 0.285 & 0.293 & 0.317 \\
\hline R-sq between & 0.008 & 0.001 & 0.000 \\
\hline R-sq overall & 0.014 & 0.004 & 0.002 \\
\hline
\end{tabular}

Note: $\uparrow p<.10,{ }^{*} p<.05,{ }^{* *} p<.01,{ }^{* * *} p<.001$. Dependent variable: market capitalization t. All models include year fixed-effects. Regression with standardized coefficients. $\mathrm{N}=1,203$ observations, clustered in 154 firms.

emphasis on digital transformation and firm size on market capitalization was included into the regression model (Model 3), we were able to explain 31.7\% of variance within our firms. This model provided a higher goodness of fit than a model only with control variables (Model 1, R-sq. within $=28.5 \%$ ), and a model with main effects of strategic emphasis on digital transformation and firm size (Model 2, R-sq. within $=29.3 \%)$. The interaction effect between strategic emphasis on digital transformation and firm size on market capitalization was positive and significant $(\beta=0.252, \mathrm{p}<0.01$, Model 3$)$. Figure 1 illustrates this relationship. A simple slope analysis revealed, that if $\mathrm{Z}$-scores of firm size were less or equal to -1.190 (small to medium firm size), the average marginal effects of strategic emphasis on digital transformation on market capitalization were negative and significant ( $\mathrm{p}<0.01$ ). If $\mathrm{Z}$-scores of firm size were greater or equal to 0.810 (large firm size), the average marginal effects of strategic emphasis on digital transformation on market capitalization were positive and significant $(\mathrm{p}<0.01)$. Therefore, our Hypothesis was supported.

\subsection{Endogeneity and robustness checks}

To ensure that our independent variable, strategic emphasis on digital transformation, was not endogenous, i.e., correlated with an error term, e.g. due to omitted variables [57], we conducted two endogeneity tests. First, we used an instrumental variables approach by finding two proxy variables for strategic emphasis on digital transformation [56, 57]. As such instrumental variables we used an average strategic emphasis on digital transformation as well as an average prevalence of a CDO among firm's peers from the same industry in our sample [61].

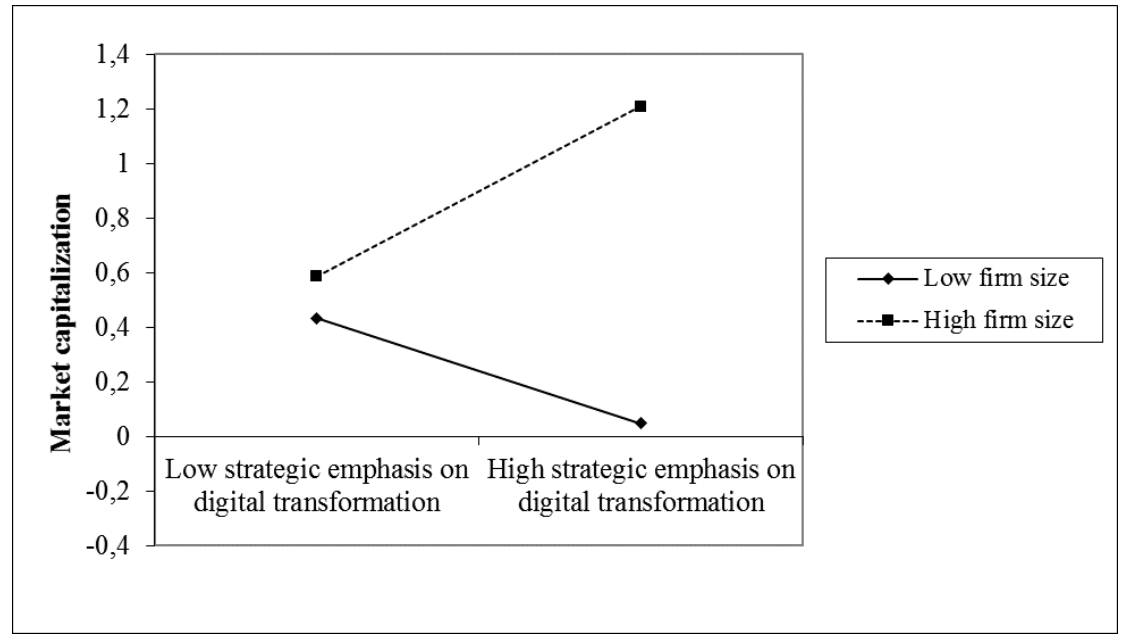

Figure 1. Interaction between strategic emphasis on digital transformation and firm size 
These instruments can be considered as appropriate, because on the one hand, they are unlikely to be correlated with the focal firm's omitted variables, and on the other hand, firms from the same industry face a similar market situation and are likely to have similar expectations about it [61]. Utilizing these instrumental variables, we ran a generalized two stage least squares regression and calculated an endogeneity test. As a result, the test was not significant (Chi-sq. $=1.252, \mathrm{p}=$ 0.535 ), indicating no evidence of endogeneity. Second, we used a control function approach by regressing strategic emphasis on digital transformation on all the other independent variables and the two instrumental variables, obtaining the residuals, and adding them to the estimation function of our dependent variable, market capitalization $[57,62]$. As a result, the coefficient of the residuals was not significant $(\beta=$ $35.338, \mathrm{p}=0.213$ ), letting us conclude that strategic emphasis on digital transformation was not endogenous [57].

To verify the results of our hypothesis testing, we conducted several robustness checks. First, we repeated our analysis only for the period between 2010 and 2017, as during the last decade, companies have started to pay a considerably higher attention to the digital transformation topics [5, 7]. Second, we considered the period from 2000 to 2017, but utilized a slightly different measure for strategic emphasis on digital transformation, by using only an absolute number of words, beginning with "digit*", from firms' annual reports, while including the total number of words in the report as a control variable [31]. Third, we used a different operationalization of strategic emphasis on digital transformation, by counting the words, beginning with "digit*", only in firm's letters to shareholders, which are published in annual reports, dividing this word count by the total number of words in the letter, and multiplying the result with a factor of 1,000 [43, 48, 63]. Fourth, we measured strategic emphasis on digital transformation as the absolute number of words, beginning with "digit*", in firm's letters to shareholders, while controlling for the total number of words in the letter [31, 43, 48, 63]. Fifth, we repeated the analysis by using another operationalization of firm size, which we calculated as a natural logarithm of firm sales [43]. Our results remained robust in each of these robustness checks.

\section{Discussion}

In this study, we analyzed the joint impact of firm strategic emphasis on digital transformation and firm size on market capitalization. To perform this analysis, we used a panel data set of largest German publicly listed companies between 2000 and 2017. Our results revealed that a higher firm strategic emphasis on digital transformation leads to a higher market capitalization for larger firms and to a lower market capitalization for smaller firms.

We explain these results relying on the signaling theory [17-19]. Particularly, we believe, that larger firms, embarking on a digital transformation journey, send clearer and more credible signals to investors, that they are likely to realize performance benefits, connected to digital transformation $[6,7]$, because of relying on a sufficient resources basis $[5,21,23,26-28$, 30]. As opposed to this, investors might perceive the digital transformation journey of smaller firms, having a limited resources basis, as riskier and more prone to failure [26-28].

\subsection{Theoretical implications}

With this study, we extend research on digital transformation of companies [2, 3, 5, 7, 11, 24] in two ways. First, by exploring the effect of strategic emphasis on digital transformation on firm evaluation on a stock market, we respond to a call of existing studies to investigate the questions related to success, risks and failures of digital transformation for firms [3]. Hereby, we show that an increased strategic emphasis on digital transformation leads to a higher evaluation of larger firms and to a lower evaluation of smaller firms on a stock market $[13,14]$. Hence, we demonstrate, that is might be easier for larger firms to be successful in their digital transformation endeavors [2], because they are rewarded by the stock market in a timely way. At the same time, smaller firms have to face an additional challenge [3,5] on their digital transformation paths in terms of skeptically reacting investors and decreasing market capitalization. In revealing these results, we are to our best knowledge the first to provide quantitative empirical evidence on strategic emphasis on digital transformation in firms and its influence on their performance in a longitudinal study over 17 years using panel data [7].

Second, due to examining the effects of an interplay between firm strategic emphasis on digital transformation and firm size on market capitalization, we draw attention to firm characteristics, which might promote or hamper the realization of the benefits, connected with the digital transformation process. Thus, we extend the digital transformation framework as proposed by Vial [7] by adding an outcome of positive stock market reactions in terms of increased market capitalization to the building block of positive impacts, and of negative stock market reactions in terms of decreased market capitalization to the building block of negative impacts of digital transformation. 
Additionally, we propose a further building block of contextual factors such as firm size, which might radically influence the result of the link between the changes in value creation paths and digital transformation impacts [7].

\subsection{Limitations and future research}

While the utilization of longitudinal research methods in terms of panel data analysis contributes to establishing causality in our results [64], our study has limitations. First, we faced the problem of missing data for our sample [34, 36, 37]. Among the variables used in our study, this problem especially affected firm R\&D expenditures and financial data. Although we relied on complete 1,203 firm-year observations for our analysis, the reduced sample size might limit the generalizability of our results to those firms, which did not disclose their R\&D expenditures. Further, while we controlled for R\&D expenditures to address the magnitude of the required financial resources for digital transformation [50, 51], due to the poor data availability for the HDAX firms [34, 36, 37], we were not able to control for other aspects, which might be related to digital business strategy and its risk, such as IT investments [65]. Therefore, future research may address this limitation by repeating the study using another sample with a better data availability, and in doing so, include additional control variables such as IT investments.

Second, we approached digital transformation through firm strategic emphasis on digital transformation, while controlling for the presence of a CDO. Although these aspects provide a basis for formulating and implementing a digital transformation strategy [3, 5, 20, 21, 24], it encompasses more practices such as setting up governance structures [3], working together with customers and other business partners on digital transformation projects [20], developing digital services platforms and operational backbones or generating revenue, coming from digital products or services [2]. Thus, future research may address an interplay of these aspects of digital transformation with firm size on market capitalization.

Third, our measure of strategic emphasis on digital transformation was based on the count of words, beginning with "digit*", in firms' annual reports. Although our analysis of the most frequently used words, beginning with this word root, indicated topics, connected with digital transformation of companies, we cannot rule out a potential bias, which could arise if firms would use these words differently depending on their industry. Hence, future research might investigate the exact meaning of the words, used by companies from different industries.
Fourth, even HDAX generates a considerable amount of variance with respect to firm size [34], we have to acknowledge that even the smallest company in our sample still had a market capitalization of multiple million. Thus, future research might explore the relationship between strategic emphasis on digital transformation and firm size on market capitalization by considering smaller firms.

\subsection{Practical implications}

Our study is also important for practitioners, who are embarking on a digital transformation journey [3, 5]. First, we draw attention of practitioners to the fact, that strategic emphasis on digital transformation, as signaled by their firms, can matter for firm market capitalization. Second, we provide evidence, that larger firms might anticipate a higher market capitalization as a result of signaling a higher strategic emphasis on digital transformation. Thus, larger companies can be advised to continue disclosing their strategic emphasis on digital transformation, while paying attention also to other signals, which they send in this respect to the public. At the same time, smaller companies might have a more difficult start $[3,5]$ on their digital transformation paths because investors can react to their signaling of a higher strategic emphasis on digital transformation skeptically, leading to a decreased market capitalization. Hence, smaller firms should be aware of these possible difficulties and should consider sending other signals to investors, demonstrating that they are able to successfully undergo and manage digital transformation as well as risks, associated with it. With these results, we aim at supporting firms on their digital transformation paths.

\section{References}

[1] Parker, G., Van Alstyne, M., and Jiang, X., "Platform Ecosystems: How Developers Invert the Firm," MIS Quarterly, 41(1), 2017, pp. 255-A4.

[2] Sebastian, I.M., Ross, J.W., Beath, C., Mocker, M., Moloney, K.G., and Fonstad, N.O., "How Big Old Companies Navigate Digital Transformation," MIS Quarterly Executive, 16(3), 2017, pp. 197-213.

[3] Chanias, S., Myers, M.D., and Hess, T., "Digital Transformation Strategy Making in Pre-Digital Organizations: The Case of a Financial Services Provider," The Journal of Strategic Information Systems, 28(1), 2019, pp. 17-33.

[4] Forbes. (2019, June 4th, 2019). The World's Largest Public Companies. Available: https://www.forbes.com/global2000/list/

[5] Hess, T., Matt, C., Benlian, A., and Wiesböck, F., "Options for Formulating a Digital Transformation Strategy," MIS Quarterly Executive, 15(2), 2016, pp. 123-139. 
[6] Fitzgerald, M., Kruschwitz, N., Bonnet, D., and Welch, M., "Embracing Digital Technology: A New Strategic Imperative," MIT Sloan Management Review, 55(2), 2013, pp. 1-12.

[7] Vial, G., "Understanding Digital Transformation: A Review and a Research Agenda," The Journal of Strategic Information Systems, 28(2), 2019, pp. 118-144.

[8] El Sawy, O.A., Kræmmergaard, P., Amsinck, H., and Vinther, A.L., "How Lego Built the Foundations and Enterprise Capabilities for Digital Leadership," MIS Quarterly Executive, 15(2), 2016, pp. 141-166.

[9] Dremel, C., Wulf, J., Herterich, M.M., Waizmann, J.-C., and Brenner, W., "How Audi Ag Established Big Data Analytics in Its Digital Transformation," MIS Quarterly Executive, 16(2), 2017, pp. 81-100.

[10] Sia, S.K., Soh, C., and Weill, P., "How Dbs Bank Pursued a Digital Business Strategy," MIS Quarterly Executive, 15(2), 2016, pp. 105-121.

[11] Hansen, R. and Siew Kien, S., "Hummel's Digital Transformation toward Omnichannel Retailing: Key Lessons Learned," MIS Quarterly Executive, 14(2), 2015, pp. 51-66.

[12] Smith, H.A. and Watson, R.T., "Digital Transformation at Carestream Health," MIS Quarterly Executive, 18(4), 2018, pp. 85-98.

[13] Kohli, R., Devaraj, S., and Ow, T.T., "Does Information Technology Investment Influence a Firm's Market Value? A Case of Non-Publicly Traded Healthcare Firms," MIS Quarterly, 36(4), 2012, pp. 1145-1163.

[14] Dehning, B., Richardson, V.J., and Zmud, R.W., "The Value Relevance of Announcements of Transformational Information Technology Investments," MIS Quarterly, 27(4), 2003, pp. 637-656.

[15] Rubera, G. and Tellis, G.J., "Spinoffs Versus Buyouts: Profitability of Alternate Routes for Commercializing Innovations," Strategic Management Journal, 35(13), 2014, pp. 2043-2052.

[16] Berghaus, S. and Back, A., "Disentangling the Fuzzy Front End of Digital Transformation: Activities and Approaches," in 38th International Conference on Information Systems, Seoul, South Korea, 2017: Association for Information Systems.

[17] Bergh, D.D., Connelly, B.L., Ketchen Jr, D.J., and Shannon, L.M., "Signalling Theory and Equilibrium in Strategic Management Research: An Assessment and a Research Agenda," Journal of Management Studies, 51(8), 2014, pp. 1334-1360.

[18] Connelly, B.L., Certo, S.T., Ireland, R.D., and Reutzel, C.R., "Signaling Theory: A Review and Assessment," Journal of Management, 37(1), 2011, pp. 39-67.

[19] Spence, M., "Job Market Signaling," The Quarterly Journal of Economics, 87(3), 1973, pp. 355-374.

[20] Horlacher, A. and Hess, T., "What Does a Chief Digital Officer Do? Managerial Tasks and Roles of a New C-Level Position in the Context of Digital Transformation," in 49th Hawaii International Conference on System Sciences (HICSS), Koloa, HI, 2016, pp. 5126-5135: IEEE.

[21] Matt, C., Hess, T., and Benlian, A., "Digital Transformation Strategies," The Journal of Strategic Information Systems, 57(5), 2015, pp. 339-343.

[22] Eden, R., Jones, A.B., Casey, V., and Draheim, M., "Digital Transformation Requires Workforce
Transformation," MIS Quarterly Executive, 18(1), 2019, pp. $1-17$.

[23] Kirca, A.H. et al., "Firm-Specific Assets, Multinationality, and Financial Performance: A MetaAnalytic Review and Theoretical Integration," Academy of Management Journal, 54(1), 2011, pp. 47-72.

[24] Singh, A. and Hess, T., "How Chief Digital Officers Promote the Digital Transformation of Their Companies," MIS Quarterly Executive, 16(1), 2017, pp. 1-17.

[25] Hartl, E. and Hess, T., "The Role of Cultural Values for Digital Transformation: Insights from a Delphi Study," in 23rd Americas Conference on Information Systems, Boston, MA, 2017.

[26] Audia, P.G. and Greve, H.R., "Less Likely to Fail: Low Performance, Firm Size, and Factory Expansion in the Shipbuilding Industry," Management Science, 52(1), 2006, pp. 83-94.

[27] Bruderl, J. and Schussler, R., "Organizational Mortality: The Liabilities of Newness and Adolescence," Administrative Science Quarterly, 35(3), 1990, pp. 530-547.

[28] Mitchell, W., "The Dynamics of Evolving Markets: The Effects of Business Sales and Age on Dissolutions and Divestitures," Administrative Science Quarterly, 39(4), 1994, pp. 575-602.

[29] Gaba, V., Pan, Y., and Ungson, G.R., "Timing of Entry in International Market: An Empirical Study of U.S. Fortune 500 Firms in China," Journal of International Business Studies, 33(1), 2002, pp. 39-55.

[30] Levinthal, D.A., "Random Walks and Organizational Mortality," Administrative Science Quarterly, 36(3), 1991, pp. 397-420.

[31] Guo, W., Yu, T., and Gimeno, J., "Language and Competition: Communication Vagueness, Interpretation Difficulties, and Market Entry," Academy of Management Journal, 60(6), 2017, pp. 2073-2098.

[32] Schryen, G., "Revisiting Is Business Value Research: What We Already Know, What We Still Need to Know, and How We Can Get There," European Journal of Information Systems, 22(2), March 01 2013, pp. 139-169.

[33] Deutsche Börse Group, "Hdax: Index, Der Die Wertentwicklung Aller Aktien in Dax ${ }^{\circledR}, \operatorname{Mdax}{ }^{\circledR}$ Und Tecdax ${ }^{\circledR}$ Abbildet," Accessed on: 20 February 2019Available: https://deutsche-boerse.com/dbg-de/ueberuns/services/know-how/boersenlexikon/boersenlexikonarticle/HDAX-246222

[34] Tuschke, A., Sanders, W.M.G., and Hernandez, E., "Whose Experience Matters in the Boardroom? The Effects of Experiential and Vicarious Learning on Emerging Market Entry," Strategic Management Journal, 35(3), 2014, pp. 398418.

[35] Flickinger, M., Wrage, M., Tuschke, A., and Bresser, R., "How Ceos Protect Themselves against Dismissal: A Social Status Perspective," Strategic Management Journal, 37(6), 2016, pp. 1107-1117.

[36] Sanders, W.G. and Tuschke, A., "The Adoption of Institutionally Contested Organizational Practices: The Emergence of Stock Option Pay in Germany," Academy of Management Journal, 50(1), 2007, pp. 33-56.

[37] Tuschke, A. and Gerard Sanders, W., "Antecedents and Consequences of Corporate Governance Reform: The Case 
of Germany," Strategic Management Journal, 24(7), 2003, pp. 631-649.

[38] Xia, J., Dawley, D.D., Jiang, H., Ma, R., and Boal, K.B., "Resolving a Dilemma of Signaling Bankrupt-Firm Emergence: A Dynamic Integrative View," Strategic Management Journal, 37(8), 2016, pp. 1754-1764.

[39] Stern, I. and James, S.D., "Whom Are You Promoting? Positive Voluntary Public Disclosures and Executive Turnover," Strategic Management Journal, 37(7), 2016, pp. 1413-1430.

[40] Hoehn-Weiss, M.N. and Karim, S., "Unpacking Functional Alliance Portfolios: How Signals of Viability Affect Young Firms' Outcomes," Strategic Management Journal, 35(9), 2014, pp. 1364-1385.

[41] Joshi, A. and Hanssens, D.M., "The Direct and Indirect Effects of Advertising Spending on Firm Value," Journal of Marketing, 74(1), 2010, pp. 20-33.

[42] Tanriverdi, H., "Performance Effects of Information Technology Synergies in Multibusiness Firms," MIS Quarterly, 30(1), 2006, pp. 57-77.

[43] Shin, T. and You, J., "Pay for Talk: How the Use of Shareholder-Value Language Affects Ceo Compensation," Journal of Management Studies, 54(1), 2017, pp. 88-117.

[44] Lehavy, R., Feng, L., and Merkley, K., "The Effect of Annual Report Readability on Analyst Following and the Properties of Their Earnings Forecasts," Accounting Review, 86(3), 2011, pp. 1087-1115.

[45] Jegadeesh, N. and Wu, D., "Word Power: A New Approach for Content Analysis," Journal of Financial Economics, 110(3), 2013/12/01/ 2013, pp. 712-729.

[46] Liebmann, M., Hagenau, M., and Neumann, D., "Information Processing in Electronic Markets: Measuring Subjective Interpretation Using Sentiment Analysis," in 33rd International Conference on Information Systems (ICIS), Orlando, FL, 2012, pp. 1-18.

[47] Schäfferling, A. and Wagner, H.-T., "Do Investors Recognize Information Technology as a Strategic Asset? A Longitudinal Analysis of Changes in Ownership Structure and It Capability," in 21st European Conference on Information Systems (ECIS), Utrecht, Netherlands, 2013, pp. $1-12$.

[48] Gamache, D.L., McNamara, G., Mannor, M.J., and Johnson, R.E., "Motivated to Acquire? The Impact of Ceo Regulatory Focus on Firm Acquisitions," Academy of Management Journal, 58(4), 2015, pp. 1261-1282.

[49] Chen, J.-S., Tsou, H.-T., and Ching, R.K.H., "CoProduction and Its Effects on Service Innovation," Industrial Marketing Management, 40(8), 2011, pp. 1331-1346.

[50] Kim, K., Mithas, S., and Kimbrough, M., "Information Technology Investments and Firm Risk across Industries: Evidence from the Bond Market," MIS Quarterly, 41(4), 2017, pp. 1347-15-A13.

[51] Wunderlich, N. and Beck, R., "You'll Be Surprised Digital Business Strategy as Driver of Organizational Innovativeness," in 51st Hawaii International Conference on System Sciences (HICSS), Waikoloa Village, HI, 2018, pp. 4035-4044: IEEE.

[52] Mithas, S., Tafti, A., Bardhan, I., and Mein Goh, J., "Information Technology and Firm Profitability: Mechanisms and Empirical Evidence," MIS Quarterly, 36(1), 2012, pp. 205-224.
[53] Cincera, M. and Veugelers, R., "Differences in the Rates of Return to R\& D for European and Us Young Leading R\& D Firms," Research Policy, 43(8), 2014, pp. 1413-1421.

[54] Horlacher, A.A., Klarner, P.P., and Hess, T.T., "Crossing Boundaries: Organization Design Parameters Surrounding Cdos and Their Digital Transformation Activities," in 22nd Americas Conference on Information Systems, San Diego, CA, 2016.

[55] Calabrò, A., Minichilli, A., Amore, M.D., and Brogi, M., "The Courage to Choose! Primogeniture and Leadership Succession in Family Firms," Strategic Management Journal, 39(7), 2018, pp. 2014-2035.

[56] Certo, S.T., Withers, M.C., and Semadeni, M., "A Tale of Two Effects: Using Longitudinal Data to Compare withinand between-Firm Effects," Strategic Management Journal, 38(7), 2017, pp. 1536-1556.

[57] Wooldridge, J., Introductory Econometrics: A Modern Approach, 5 ed. Mason, OH: South-Western Cengage Learning, 2012.

[58] Belderbos, R., Tong, T.W., and Wu, S., "Multinationality and Downside Risk: The Roles of Option Portfolio and Organization," Strategic Management Journal, 35(1), 2014, pp. 88-106.

[59] Hair, J.F., Black, W., Babin, B.J., Anderson, R.E., and Tatham, R.L., Multivariate Data Analysis, 7 ed. Englewood Cliff, NJ: Prentice Hall, 2009.

[60] Saunders, M., Lewis, P., and Thornhill, A., Research Methods for Business Students, 4 ed. Essex, England: Pearson Education Limited, 2007.

[61] Germann, F., Ebbes, P., and Grewal, R., "The Chief Marketing Officer Matters!," Journal of Marketing, 79(3), 2015, pp. 1-22.

[62] Petrin, A. and Train, K., "A Control Function Approach to Endogeneity in Consumer Choice Models," Journal of Marketing Research, 47(1), 2010, pp. 3-13.

[63] Gamache, D.L. and McNamara, G., "Responding to Bad Press: How Ceo Temporal Focus Influences the Sensitivity to Negative Media Coverage of Acquisitions," Academy of Management Journal, 62(3), 2019, pp. 918-943.

[64] Podsakoff, P.M., MacKenzie, S.B., and Podsakoff, N.P., "Sources of Method Bias in Social Science Research and Recommendations on How to Control It," Annual Review of Psychology, 63(1), 2012, pp. 539-569.

[65] Mithas, S., Tafti, A., and Mitchell, W., "How a Firm's Competitive Environment and Digital Strategic Posture Influence Digital Business Strategy " MIS Quarterly, 37(2), 2013, pp. 511-536. 